\title{
Educational program for coronary artery disease patients: results after one year
}

\author{
Programa educativo para pacientes com doença arterial coronariana: resultados após um ano \\ Programa educativo para pacientes con enfermedad arterial coronaria: resultados después de un año
}

\section{Eliana de Cássia Arantes', Carina Aparecida Marosti Dessotte', Rosana Aparecida Spadoti Dantas', Lidia Aparecida Rossi', Rejane Kiyomi Furuya"}

'Universidade de São Paulo, Ribeirão Preto College of Nursing. Ribeirão Preto, São Paulo, Brazil.

"Instituto Federal do Paraná. Londrina, Paraná, Brazil.

Como citar este artigo:

Arantes EC, Dessotte CAM, Dantas RAS, Rossi LA, Furuya RK. Educational program for coronary artery disease patients: results after one year. Rev Bras Enferm [Internet]. 2018;71(6):2938-44. DOI: http://dx.doi.org/10.1590/0034-7167-2017-0280

Submission: 05-09-2017

Approval: 04-20-2018

\section{ASTRACT}

Objective: To evaluate the long-term results of an educational program compared to usual care. Method: A longitudinal study in which 56 participants from a previous study (randomized controlled clinical trial) were evaluated twelve months after the percutaneous coronary intervention ( $\mathrm{PCl})$. Health-related quality of life (HRQoL) was assessed by the Medical Outcomes Study: 36-item Short Form (SF-36), and anxiety and depression symptoms were assessed by the Hospital Anxiety and Depression Scale (HADS). A repeated measures analysis of variance was performed (significance level 0.05). Results: Participants in the educational program showed improvement of HRQoL in the Role-Emotional domain, while those in the usual care did not present changes $(p=0.05)$. Both groups showed improvement in the Role-Physical $(p=0.001)$ and Bodily Pain $(p=0.01)$ domains over time. There were no differences in the symptoms of anxiety and depression. Conclusion: One year after the $\mathrm{PCl}$, there were significant differences between groups only for the Role-Emotional domain of the SF-36.

Descriptors: Coronary Disease; Angioplasty; Health Education; Cardiac Rehabilitation; Telemedicine.

\section{RESUMO}

Objetivo: Avaliar resultados em longo prazo de um programa educativo comparado com o cuidado usual. Método: Estudo longitudinal com 56 participantes de um estudo prévio (ensaio clínico controlado e aleatorizado), que foram avaliados doze meses após intervenção coronária percutânea (ICP). A qualidade de vida relacionada à saúde (QVRS) foi avaliada pelo Medical Outcomes Study: 36-Item Short Form (SF-36) e os sintomas de ansiedade e depressão pela Hospital Anxiety and Depression Scale (HADS). Foi realizada análise de variância de medidas repetidas (nível de significância 0,05). Resultados: Os participantes do programa educativo apresentaram melhora da QVRS, no domínio Aspectos Emocionais, enquanto aqueles do cuidado usual não apresentaram alteração $(p=0,05)$. Com o tempo, ambos os grupos apresentaram melhora nos domínios Aspectos Físicos $(p=0,001)$ e Dor $(p=0,01)$. Não houve diferenças nos sintomas de ansiedade e depressão. Conclusão: Um ano após a ICP, houve diferenças significativas entre os grupos apenas para o domínio Aspectos Emocionais do SF-36.

Descritores: Doença das Coronárias; Angioplastia; Educação em Saúde; Reabilitação Cardíaca; Telemedicina.

\section{RESUMEN}

Objetivo: Evaluar resultados a largo plazo de un programa educativo comparado con el cuidado usual. Método: Estudio longitudinal con 56 participantes de un estudio previo (ensayo clínico controlado y aleatorizado), que fueron evaluados 12 meses después de la intervención coronaria percutánea (ICP). La calidad de vida relacionada con la salud (CVRS) fue evaluada por el Cuestionario de Salud SF-36 (36-Item Short Form) y los síntomas de ansiedad y depresión por la Escala de Ansiedad y Depresión Hospitalaria (sigla en inglés: HADS). Se realizó un análisis de varianza de medidas repetidas (nivel de significancia 0,05). Resultados: Los participantes del programa educativo presentaron mejoría de la CVRS en el dominio Rol Emocional, mientras que los participantes del cuidado usual no presentaron alteración $(p=0,05)$. Con el tiempo, ambos grupos presentaron mejoría en los dominios Rol 
Físico $(p=0,001)$ y Dolor Corporal $(p=0,01)$. No hubo diferencias en los síntomas de ansiedad y depresión. Conclusión: Un año después de la ICP, hubo diferencias significativas entre los grupos sólo para el dominio Rol Emocional del SF-36.

Descriptores: Enfermedad de las Coronarias; Angioplastia; Educación en Salud; Rehabilitación Cardiaca; Telemedicina.

CORRESPONDING AUTHOR Lidia Aparecida Rossi E-mail: rizzardo@eerp.usp.br

\section{INTRODUCTION}

Coronary artery disease (CAD) is one of the most important causes of morbidity and mortality in the adult population ${ }^{(1)}$. Percutaneous coronary intervention $(\mathrm{PCl})$ is one of the forms of CAD treatment, and an important group of technologies in interventional cardiology. It is indicated to increase survival and/ or relieve CAD symptoms as a less invasive option compared to myocardial revascularization surgery ${ }^{(2)}$.

For a better understanding of the impact of $\mathrm{CAD}$ and reaching better results in patients' health, studies have been conducted in order to monitor their clinical evolution ${ }^{(3)}$ and evaluate the effects of educational interventions that favor cardiac rehabilitation $^{(4-5)}$, contribute to reducing the number of readmissions and, consequently, the cost of treatment ${ }^{(6)}$, and provide better health-related quality of life $(\mathrm{HRQOL})^{(4,7)}$. Health education for patients with CAD is an essential component that assists in the management of patients' health condition and secondary prevention of disease ${ }^{(8)}$.

The World Health Organization published a comprehensive plan of action for the prevention and control of noncommunicable diseases, and cardiovascular disorders were cited as one of the major diseases ${ }^{(9)}$. The following actions described in the action plan stand out: 1) to take actions to empower people in managing their health conditions; 2) to promote education, incentives and tools for self-care and self-management that are based on guidelines and patient records, and a team based on patient management ${ }^{(9)}$.

Thus, there should be greater emphasis on interventions focused on the education of patients with CAD and directed mainly to low-income patients, and themes related to the awareness of risk factors, such as alert symptoms and actions that should be taken in cardiovascular emergency situations ${ }^{(10)}$.

Systematic ${ }^{(11)}$ and integrative reviews ${ }^{(12)}$ did not present conclusive results on long-term effects of educational programs with telephone follow-up in patients with CAD. In the cited reviews ${ }^{(11-12)}$, were included studies conducted predominantly in developed countries, and was found the need for clinical trials with greater methodological rigor.

In Brazil, studies of cardiac rehabilitation interventions performed by nurses are scarce. All knowledge developed in these studies is necessary to elucidate the important proposals and possible innovations in clinical practice of cardiac rehabilitation nurses.

Thus, in the present study, we used data of a previous study ${ }^{(4)}$ for the evaluation of long-term effects of an educational program in which participants in the intervention group (IG) received an educational program with telephone follow-up, and participants in the control group (CG) received the usual care. Participants of the IG were compared with those of the CG at admission and one year after the PCI. The evaluated outcomes were HRQoL and the symptoms of anxiety and depression.

\section{OBJECTIVE}

To evaluate long-term outcomes of an educational program compared to usual care.

\section{METHOD}

\section{Ethical aspects}

For the development of this study, the Research Ethics Committee (REC) was asked for an addendum to the Hospital das Clínicas de Ribeirão Preto, and obtained the approval. The ethical precepts of Resolution CNS 466/12 were followed, which included obtaining written consent in two copies (one filed by the investigator and the other given to study participants).

\section{Design, place of study and period}

Observational longitudinal study. It was conducted at the Hospital das Clínicas de Ribeirão Preto, a high complexity public hospital located in the interior of the State of São Paulo. The hospital provides assistance predominantly to patients of the Unified Health System (Portuguese acronym: SUS). The evaluation one year after the $\mathrm{PCl}$ was done between September 2012 and June 2013.

\section{Population or sample: inclusion and exclusion criteria}

Participants of this study were part of a previous study ${ }^{(4)}$, in which the sample was recruited between August 2011 and June 2012. Inclusion criteria established in that study ${ }^{(4)}$ were the following: adult patients (18 years of age or older) who underwent $\mathrm{PCl}$ for the first time, and owners of a telephone line that worked properly. Exclusion criteria were patients with no adequate cognitive conditions and who did not have clinical (physical or psychological) conditions to answer the questionnaires $^{(4)}$.

In the previous study ${ }^{(4)}, 60$ subjects undergoing $\mathrm{PCl}$ were followed-up for six months. Participants of the IG (30) received an educational program containing individual care, health care guidance booklets and three telephone contacts (first, eighth and sixteenth week after hospital discharge), in which the aim was to stimulate self-care. Participants of the CG (30) received guidelines according to hospital routine ${ }^{(4)}$. The present study continued the study conducted by these authors. The same 60 individuals were recruited by telephone one year after the PCI. Out of these, four did not attend the meetings scheduled for evaluation one year after the $\mathrm{PCl}$. Thus, the present study had a sample of 56 participants $(\mathrm{IG}=29$ and $\mathrm{CG}=27$ ). 


\section{Study protocol}

Participants' data obtained at admission (Time zero - T0) were collected in the previous study ${ }^{(4)}$ in the Section of Hemodynamics and Interventional Cardiology with elective patients on the day scheduled for performing the $\mathrm{PCl}$.

In the present study, in the evaluation of patients 12 months after the PCI (Time 1 - T1), data collection was performed between 11 and 15 months after the $\mathrm{PCl}$ in the cardiology outpatient clinic or in a scheduled setting according to participants' convenience. Out of the 60 participants in the intervention study ${ }^{(4)}, 45$ were evaluated in outpatient clinics of the hospital where that study was performed on the dates according to the follow-up scheduled. Fifteen participants were referred for continuity of treatment in their city of origin six months after the PCl. For these subjects, first was made a telephone contact, and after they demonstrated interest in continuing the survey, the collection of data was scheduled at their residence or other location established by them. Among the 15 participants, four did not attend the follow-up. Further attempts of contact were made by telephone without success.

In the previous study before the $\mathrm{PCl}$, in the initial evaluation (T0), were collected data for sociodemographic and clinical characterization, HRQoL assessment, presence of anxiety and depression symptoms, self-efficacy and adherence to medications. In the present study, in the evaluation of patients 12 months after the $\mathrm{PCl}(\mathrm{T} 1)$ were applied the same instruments used in the initial measurement (TO) for assessment of HRQoL and symptoms of anxiety and depression.

For HRQoL assessment, was used the Portuguese validated version of the Medical Outcomes Study 36 - Item Short-Form Health Survey (SF-36) ${ }^{(13)}$. The SF-36 is a multidimensional instrument that measures eight health domains, namely: Social Functioning, Physical Functioning, General Health, Vitality, Mental Health, Role-Emotional, Bodily Pain and Role-Physical. Each domain has a 0-100 score, and higher values represent a better HRQoL. When evaluating the internal consistency of this instrument in a study with CAD patients with similar characteristics, Cronbach's alpha values found were 0.71 and 0.97 for domains of General Health and Role-Emotional, respectively ${ }^{(3)}$.

The Portuguese validated version of the Hospital Anxiety and Depression Scale (HADS) was used to evaluate the symptoms of anxiety and depression ${ }^{(14)}$. The HADS is a 14-item instrument divided into two subscales: anxiety and depression. Each subscale has seven items and the score for each ranges from 0 to 21 . Higher values indicate more symptoms of anxiety and depression. In the validation, were found Cronbach's alpha values of 0.68 and 0.77 for the Anxiety and Depression subscales, respectively ${ }^{(14)}$.

Previously collected data were updated ${ }^{(4)}$ with use of the sociodemographic and clinical characterization instrument proposed by the authors. Through an individual interview, was collected information regarding age, years of study, address, telephone, best time to find participant at home, marital status, performance of paid occupational activities, and monthly family income, as well as clinical data, such as undergoing a new $\mathrm{PCl}$ or new hospitalization.
The instruments were always applied in the same order, through a face-to-face interview. The average duration of each interview was 60 minutes.

\section{Analysis of results and statistics}

Data were entered and analyzed by using the Statistical Package for the Social Sciences (IBM SPSS version 22.0) for Windows. Descriptive analyzes of simple frequency were performed for categorical variables (sex, marital status, performance of paid occupational activities, type of $\mathrm{PCl}$, and readmissions). Analysis of central tendency (mean) and variability (standard deviation - SD) were performed for numerical variables (age, years of study, number of dependents, monthly family income) and scale variables (SF-36 and HADS).

In order to assess changes in HRQoL, anxiety and depression symptoms, were used repeated measures analysis of variance (ANOVA), using factors of time (initial evaluation and 12 month-evaluation), group (intervention and control) and one interaction (time $x$ group). The interaction evaluated whether the groups had different patterns of improvement by taking into consideration that participants from both groups would have improvement in HRQoL and of symptoms of anxiety and depression over time. The level of significance was set at 0.05.

\section{RESULTS}

The sociodemographic characterization data of the 56 participants of this study are presented in Table 1, according to the allocation.

Participants of the CG and IG remained homogeneous in relation to sociodemographic characterization when comparing data at $\mathrm{T} 0$ and $\mathrm{T} 1$. In the evaluation 12 months after the $\mathrm{PCl}$, the mean ages of IG and CG participants were 64.6 years and 61.3 years, respectively. Most were married or lived in consensual union $(\mathrm{IG}=72.4 \% ; \mathrm{CG}=70.4 \%)$, male $(\mathrm{IG}=58.6 \% ; \mathrm{CG}=51.9 \%)$ and $\mathrm{did}$ not perform paid occupational activities ( $\mathrm{IG}=82.8 \%$; $C \mathrm{CG}=66.7 \%$ ).

Nine participants were rehospitalized within one year after the PCl, of which four of the IG and five patients of the CG. Of these participants, eight underwent a new $\mathrm{PCl}$, one had angina and was maintained in clinical treatment.

Table 2 shows the means obtained for each of the eight domains of the SF-36 (HRQoL measure) and for HADS subscales (measures of anxiety and depression symptoms) before the $\mathrm{PCI}^{(4)}$ and 12 months after the procedure. In the assessment before the $\mathrm{PCl}$, there were no statistically significant differences between groups for mean HRQoL scores (eight SF-36 domains), and anxiety and depression symptoms $\mathrm{s}^{(4)}$.

In the initial assessment (T0) in both groups, was reported a better HRQoL in the Social Functioning domain (CG $=69.9$; $I G=74.6$ ) and worse HRQoL in the Role-Physical domain $(C G=32.4 ; I G=29.3)$. Likewise, twelve months after the $P C I(T 1)$, participants from both groups had better HRQoL in the Social Functioning domain $(C G=72.7 ; \mathrm{IG}=81.9)$ and worse HRQoL in the Role-Physical domain ( $C G=51.8$; IG =55.2) (Table 2).

The effects of time and the intervention were evaluated with the ANOVA by using the following factors: time, group and interaction (time $\mathrm{x}$ group) (Table 3 ). 
Table 1 - Sociodemographic characterization of subjects at baseline time 0 (T0) before percutaneous coronary intervention ( $\mathrm{PCl}$ ), and one year after percutaneous coronary intervention (time - T1), Ribeirão Preto, São Paulo, Brazil, 2011 - 2014

\begin{tabular}{|c|c|c|c|c|c|c|}
\hline \multirow{2}{*}{ Variable } & \multicolumn{2}{|c|}{$\begin{array}{c}\text { T0 (FURUYA, 2015) } \\
\text { Before PCI }\end{array}$} & \multirow{2}{*}{$\begin{array}{c}p \\
\text { value }\end{array}$} & \multicolumn{2}{|c|}{$\begin{array}{l}\text { T1(Current study) } \\
\text { After } 12 \text { months }\end{array}$} & \multirow{2}{*}{$\begin{array}{c}p \\
\text { value }\end{array}$} \\
\hline & IG $(n=29)$ & CG $(n=27)$ & & IG $(n=29)$ & $C G(n=27)$ & \\
\hline Age (in years) $[M,(S D)]$ & $63.5(12.5)$ & $60.2(8.8)$ & 0.26 & $64.6(12.5)$ & $61.3(8.8)$ & 0.26 \\
\hline Years of study [M, (SD)] & $3.9(2.9)$ & $5.5(4.2)$ & 0.11 & $3.9(2.9)$ & $5.5(4.2)$ & 0.11 \\
\hline Number of dependents [M, (SD)] & $3.41(1.9)$ & $3.1(1.5)$ & 0.52 & $2.7(1.7)$ & $2.7(1.6)$ & 0.91 \\
\hline Monthly family income (in Reais) [M, (SD)] & $1670(1173)$ & $2579(4646)$ & 0.31 & $1362(723)$ & $1913(1339)$ & 0.06 \\
\hline $\begin{array}{l}\text { Sex } \%(n) \\
\text { Male } \\
\text { Female }\end{array}$ & $\begin{array}{l}58.6(17) \\
41.4(12)\end{array}$ & $\begin{array}{l}51.9(14) \\
48.1(13)\end{array}$ & $0.61 *$ & $\begin{array}{l}58.6(17) \\
41.4(12)\end{array}$ & $\begin{array}{l}51.9(14) \\
48.1(13)\end{array}$ & $\begin{array}{c}0.61^{*} \\
- \\
-\end{array}$ \\
\hline $\begin{array}{l}\text { Marital status \% (n) } \\
\text { Married/consensual union } \\
\text { Single/widowed or separated }\end{array}$ & $\begin{array}{r}75.8(22) \\
24.2(7)\end{array}$ & $\begin{array}{r}74.1(20) \\
25.9(7)\end{array}$ & $0.88^{*}$ & $\begin{array}{c}72.4(21) \\
24.1(8)\end{array}$ & $\begin{array}{r}70.4(19) \\
29.6(8)\end{array}$ & $0.87^{*}$ \\
\hline $\begin{array}{l}\text { Performance of paid occupational activities \% (n) } \\
\text { No } \\
\text { Yes }\end{array}$ & $\begin{array}{l}65.5(19) \\
34.5(10)\end{array}$ & $\begin{array}{l}59.3(16) \\
40.7(11)\end{array}$ & $0.63 *$ & $\begin{array}{r}82.8(24) \\
17.2(5)\end{array}$ & $\begin{array}{r}66.7(18) \\
33.3(9)\end{array}$ & $0.17^{*}$ \\
\hline
\end{tabular}

Note: $M=$ Mean; $S D=$ Standard deviation; * $p$ value from the Chi-square test (sex, marital status, performance of paid occupational activities); for the other $p$ values, test of comparison of means (Student's $t$ for independent samples).

Table 2 - Mean values of the eight SF-36 domains and of Hospital Anxiety and Depression Scale subscales of each of the groups (CG and IG) at the two evaluation times (T0 and T1), Ribeirão Preto, São Paulo, Brazil, 2011 - 2014

\begin{tabular}{|c|c|c|c|c|}
\hline \multirow{3}{*}{ Variable } & \multicolumn{2}{|c|}{ Control Group $(n=27)$} & \multicolumn{2}{|c|}{ Intervention Group $(\mathrm{n}=29)$} \\
\hline & $* \mathrm{TO}$ & $* * \mathrm{~T} 1$ & $* \mathrm{TO}$ & $* * \mathrm{~T} 1$ \\
\hline & Mean (SD) ${ }^{\mathrm{a}}$ & Mean $(S D)^{a}$ & Mean (SD) ${ }^{a}$ & Mean $(\mathrm{SD})^{\mathrm{a}}$ \\
\hline \multicolumn{5}{|l|}{ SF-36 domains } \\
\hline Social Functioning & $69.9(29.5)$ & $72.7(29.2)$ & $74.6(25.5)$ & $74.6(25.5)$ \\
\hline Vitality & $61.7(24.0)$ & $61.5(24.9)$ & $61.4(23.2)$ & $66.9(24.5)$ \\
\hline Mental Health & $61.3(19.9)$ & $63.2(13.5)$ & $60.7(13.7)$ & $65.5(14.0)$ \\
\hline General Health & $61.1(20.5)$ & $60.2(21.1)$ & $64.2(15.0)$ & $65.6(21.7)$ \\
\hline Role-Emotional & $60.5(41.4)$ & $60.5(43.4)$ & $51.7(37.3)$ & $75.9(35.5)$ \\
\hline Physical Functioning & $57.4(26.7)$ & $54.1(31.6)$ & $64.3(24.1)$ & $66.4(24.6)$ \\
\hline Bodily Pain & $39.2(34.3)$ & $59.0(27.1)$ & $45.9(37.5)$ & $56.5(28.4)$ \\
\hline Role-Physical & $32.4(33.8)$ & $51.8(43.3)$ & $29.3(34.8)$ & $55.2(44.0)$ \\
\hline \multicolumn{5}{|l|}{ HADS Subscales } \\
\hline Anxiety & $7.3(3.6)$ & $6.3(3.5)$ & $7.0(4.0)$ & $6.3(3.9)$ \\
\hline Depression & $5.5(4.0)$ & $5.9(4.3)$ & $6.5(3.9)$ & $5.3(3.4)$ \\
\hline
\end{tabular}

Note: *TO = Initial measurement collected before the PCI (FURUYA et al., 2015); ** T1 = final measurement collected 12 months after the PCI (Current study); (a) $S D=$ Standard Deviation; HADS: Hospital Anxiety and Depression Scale.

In the HRQoL assessment, in the Role-Emotional domain, an interaction (time $x$ group) and a time effect were statistically significant $(p=0.05)$. Participants of the IG presented better HRQoL for this domain over time $(\mathrm{T} 0=51.7 ; \mathrm{T} 1=75.9)$, while $\mathrm{CG}$ participants ( $\mathrm{T} 0$ and $\mathrm{T} 1=60.5$ ) did not present changes (Tables 2 and 3).

In the Role-Physical and Bodily Pain domains, the time effect $(p=0.001$ and $p=0.01$, respectively) was statistically significant, with better HRQoL over time in both groups. In the Role-Physical domain, CG participants presented mean values of 32.4 (T0) and 51.8 (T1), while participants of the IG had mean values of 29.3 (T0) and 55.2 (T1). In the Bodily Pain domain, the mean values of CG participants were 39.2 (T0) and 59.0 (T1), and of IG participants were 45.9 (T0) and 56.5 (T1) (Tables 2 and 3).

In the assessment of anxiety symptoms, CG participants had mean values of 7.3 (T0) and 6.3 (T1), while those of the IG had mean values of 7.0 (T0) and 6.3 (T1). For depression symptoms, mean scores of the CG were 5.5 (T0) and 5.9 (T1), and for the IG, mean values were 6.5 (T0) and 5.3 (T1) (Table 2). In the assessment of anxiety and depression symptoms by considering the effects of time and intervention through ANOVA, there were no statistically significant effects of any of the factors (time, group and interaction) (Table 3). 
Table 3 - $\quad P$ values of repeated measures analysis of variance (ANOVA) for the eight SF-36 domains and Hospital Anxiety and Depression Scale subscales with use of time (initial evaluation and after 12 months), group (intervention and control) and interaction (time $\mathrm{x}$ group) factors

\begin{tabular}{lccc}
\hline \multicolumn{1}{c}{ Variable } & \multicolumn{3}{c}{$p$ values by factors } \\
& Time & Group & $\begin{array}{c}\text { Interaction } \\
\text { (time x group) }\end{array}$ \\
& & & \\
\hline SF-36 Domains & & & 0.56 \\
$\quad$ Social Functioning & 0.20 & 0.24 & 0.37 \\
Vitality & 0.41 & 0.65 & 0.47 \\
Mental Health & 0.10 & 0.82 & 0.68 \\
General Health & 0.93 & 0.34 & 0.05 \\
Role-Emotional & 0.05 & 0.70 & 0.36 \\
Physical Functioning & 0.83 & 0.15 & 0.40 \\
Bodily Pain & 0.01 & 0.75 & 0.61 \\
Role-Physical & 0.001 & 0.99 & \\
HADS Subscales & & & 0.84 \\
Anxiety & 0.10 & 0.89 & 0.11 \\
Depression & 0.40 & 0.84 &
\end{tabular}

Note: $P$ values $\leq 0.05$ in bold; HADS: Hospital Anxiety and Depression Scale.

\section{DISCUSSION}

By considering the initial measurements of the previous study ${ }^{(4)}$, and one year after the $\mathrm{PCl}$, there was a statistically significant result only for the Role-Emotional domain of the SF-36. In this domain, there was a statistically significant interaction (time $x$ group) and a statistically significant time effect $(p=0.05)$ with better HRQoL in IG participants after one year, but without change among CG participants. In the previous study, six months after the $\mathrm{PCl}$, the educational intervention tested did not have the expected effects on HRQoL improvement either ${ }^{(4)}$.

In the present study, one year after the $\mathrm{PCl}$ (T1), participants in both groups had better mean scores in the Role-Physical and Bodily Pain domains of SF-36 compared to the initial assessment (T0), and the time effect was statistically significant $(p=0.001$ and $p=0.01$, respectively). In a randomized controlled clinical study, were evaluated the effects of an educational program with telephone follow-up in patients suffering from acute myocardial infarction. Six months after the initial evaluation, the authors found improvements in physical dimensions of the HRQoL (Physical Component Summary of the SF-36) $(p=0.034)$, and in the weekly frequency of exercise practice $(p=0.004)$ for participants who received the educational intervention compared to those who received usual care, and better HRQoL (most SF-36 domains) in participants of both groups ${ }^{(15)}$. However, in a new study performed with the same group of individuals 12 months after the educational intervention, the differences between groups (those who received the educational program with telephone follow-up and those who did not) in relation to the Physical Component Summary of the SF-36 were not the same. There was improvement in the HRQoL in both groups, with values equivalent to those of the normal population ${ }^{(16)}$. Perceptions of individuals from both groups on chronic disease may have changed given the knowledge acquired and the perception of improvement of symptoms after treatment ${ }^{(15-16)}$.

In a randomized controlled clinical study conducted in Germany, were evaluated 395 patients with CAD, and 196 participants received an educational program (Intervention Group). The authors had physical activity and emotional status as primary outcomes, and the secondary outcomes were knowledge of disease risk factors and disease course. The results of the study were evaluated after a mean interval of 220 days of the intervention, and showed the educational program could be a suitable means for improving patients' lifestyle and for secondary prevention of CAD ${ }^{(17)}$.

In the evaluation of anxiety and depression symptoms in the present study, no statistically significant results were found in relation to time (T0 and T1), group (GI and GC) and interaction (time $x$ group). In the evaluation of participants of the present study performed in the previous study ${ }^{(4)}$, there was a statistically significant interaction (time $x$ group) for the measure of anxiety. Anxiety symptoms decreased in IG participants after six months, but they increased among CG participants.

A recent meta-analysis on the effects of telephone follow-up on the rehabilitation of patients with CAD has shown evidence that support provided by telephone follow-up may lead to anxiety reduction ${ }^{(18)}$. The study highlighted the need for follow-up studies for periods of 12 months or more, and by taking into account there are important benefits in reducing anxiety, which may contribute to the reduction of cardiac risk and hospitalizations. Telephone support can help provide specialized preventive care to patients with more difficult access to services, and has the potential of some reduction of the health system burden. This is an important aspect for investigation in future research ${ }^{(18)}$.

Patients undergoing $\mathrm{PCl}$ or myocardial revascularization surgery should be referred for cardiovascular rehabilitation programs prior to hospital discharge or during the first consultation after the procedure ${ }^{(8)}$. However, cardiac rehabilitation programs in developing countries are scarce and poorly accessible. In addition, there are barriers to patient participation in these programs such as their high costs, patients' difficulties regarding locomotion, transportation and distance from the health service, and those related to patients' responsibilities with work and the family ${ }^{(19)}$. Cardiac rehabilitation programs with telephone follow-up can facilitate patients' adherence and have lower cost compared to programs performed in the outpatient clinic.

Results of a systematic review on telecommunication interventions (telephone, internet, videoconference) in secondary prevention for patients with CAD have shown these interventions promote effective reduction of risk factors and may increase survival ${ }^{(20)}$. Even though the frequency and duration of the intervention could not be established, the authors concluded that telecommunication health education models can assist in secondary prevention of CAD and narrow the gap between evidence of the benefits of rehabilitation programs and the difficulty of implementation in clinical practice ${ }^{(20)}$. In another systematic review of internet interventions for promoting CAD self-management, the authors concluded there is a need for more robust and well-delineated clinical trials ${ }^{(21)}$. These studies should explore how interventions work and how to improve participants' adherence to rehabilitation programs ${ }^{(21)}$. 
In 2016, the International Council of Cardiovascular Prevention and Rehabilitation (ICCPR) released strategies for implementing cardiac rehabilitation programs in developing countries ${ }^{(22)}$. According to the ICCPR, cardiac rehabilitation programs can be adapted and integrated into the primary health care system in order to be more feasible in settings ${ }^{(22)}$.

In the present study, the educational intervention tested did not have the expected long-term effects on HRQOL improvement and reduction of anxiety and depression symptoms. We consider some adjustments are needed in the educational intervention tested, namely: setting goals with the patient, developing skills and strategies for self-care, using patient outcome measures (body weight, waist circumference, and body mass index, for example), greater frequency of phone calls, or use of other features such as text messages ${ }^{(22-23)}$. Future studies may test other health education protocols with use of videos, patient evolution journals, and mobile applications.

The implementation of rehabilitation programs according to the possibilities of each location is recommended, as well as professional training on cardiac rehabilitation performed by academic institutions $^{(22)}$. New studies are needed to identify the best way to implement educational programs that consider the feasibility, cost, and results of such programs. In the evaluation of results, the outcomes should include measures of care selfmanagement, changes in lifestyle and clinical aspects (HRQoL, acute cardiovascular events, hospitalization and mortality) ${ }^{(22)}$.

\section{Limitations of the study}

We recognize limitations in the present study, and the first one is related to the size of the previous study sample ${ }^{(4)}$. Other possible limitations would be those resulting from the application of instruments through an interview. This makes participants' choice of response more difficult because of the different options presented by the instruments, especially the SF-36. There are also limitations resulting from participants' difficulty with remembering how they were in the periods covered by HADS and SF-36 questions, respectively, in the previous week and in the four previous weeks. The outcomes used in this study may also not be the most adequate for detecting such differences, if any.

Contributions to the area of nursing, health or public policy

The evaluation of the results of an educational program with telephone follow-up one year after the intervention may serve as the basis for other intervention studies. This study provides contributions for establishing the duration of telephone follow-up in patients undergoing $\mathrm{PCl}$. In addition, the present study provides a knowledge base for new studies with the aim to follow the clinical evolution of patients with CAD, including measures of HRQoL, anxiety and depression before $\mathrm{PCl}$, and one year after the procedure

\section{CONCLUSION}

Participation in an educational program with telephone followup for patients undergoing $\mathrm{PCl}$ had an effect in determining a better HRQoL only for the Role-Emotional domain. The interaction (time $x$ group) and time effect were statistically significant for this domain. That is, IG participants presented better HRQoL over time, while CG participants did not present changes.

Participation in the educational program had no effect in determining reduction of anxiety and depression symptoms one year after the $\mathrm{PCl}$.

Twelve months after the $\mathrm{PCl}$, participants from both groups had better HRQoL in the Role-Physical and Bodily Pain domains, with a statistically significant time effect.

The development of new longitudinal studies is recommended for evaluating the efficacy of health education interventions to patients with CAD with telephone follow-up, as well as individual and group interventions and evaluation.

\section{FUNDING}

Study funded by the São Paulo Research Foundation (Fundação de Amparado à Pesquisa do Estado de São Paulo - FAPESP) under number 2010/10006-8.

\section{REFERENCES}

1. World Health Organization-WHO. The top 10 causes of death[Internet]. Geneva: WHO; $2016[$ cited 2017 Jan 26]. Available from: http://www.who.int/mediacentre/factsheets/fs310/en/

2. Levine GN, Bates ER, Blankenship JC, Bailey SR, Bittl JA, Cercek B, et al. 2011 ACCF/AHA/SCAI guideline for percutaneous coronary intervention: a report of the American College of Cardiology Foundation/American Heart Association Task Force on Practice Guidelines and the Society for Cardiovascular Angiography and Interventions. Catheter Cardiovasc Interv[Internet]. 2013[cited 2017 Apr 11];82(4):E266-355. Available from: http://onlinelibrary.wiley.com/doi/10.1002/ccd.23390/epdf

3. Dessotte CAM, Dantas RAS, Schmidt A, Rossi LA. Health-related quality of life in patients admitted after a first episode of acute coronary syndrome. Rev Latino-Am Enfermagem[Internet]. 2011[cited 2017 Apr 11];19(5):1106-13. Available from: http://www. scielo.br/pdf/rlae/v19n5/07.pdf

4. Furuya RK, Arantes EC, Dessotte CA, Ciol MA, Hoffman JM, Schmidt A, et al. A randomized controlled trial of an educational programme to improve self-care in Brazilian patients following percutaneous coronary intervention. J Adv Nurs[Internet]. 2015[cited 2017 Apr 11];71(4):895-908. Available from: http://onlinelibrary.wiley.com/doi/10.1111/jan.12568/epdf

5. Saffi MA, Polanczyk CA, Rabelo-Silva ER. Lifestyle interventions reduce cardiovascular risk in patients with coronary artery disease: a randomized clinical trial. Eur J Cardiovasc Nurs[Internet]. 2014[cited 2017 Apr 11];13(5):436-43. Available from: http://journals. sagepub.com/doi/pdf/10.1177/1474515113505396 
6. Murphy AW, Cupples ME, Smith SM, Byrne M, Byrne MC, Newell J, SPHERE study team. Effect of tailored practice and patient care plans on secondary prevention of heart disease in general practice: cluster randomised controlled trial. BMJ[Internet]. 2009[cited 2017 Apr 11];339:b4220. Available from: http://www.bmj.com/content/bmj/339/bmj.b4220.full.pdf

7. Mayer-Berger W, Simic D, Mahmoodzad J, Burtscher R, Kohlmeyer M, Schwitalla B, et al. Efficacy of a long-term secondary prevention programme following inpatient cardiovascular rehabilitation on risk and health-related quality of life in a low-education cohort: a randomized controlled study. Eur J Prev Cardiol[Internet]. 2014[cited 2017 Apr 11];21(2):145-52. Available from: http:// journals.sagepub.com/doi/pdf/10.1177/2047487312465526

8. Smith Jr SC, Benjamin EJ, Bonow RO, Braun LT, Creager MA, Franklin BA, et al. World Heart Federation and the Preventive Cardiovascular Nurses Association. AHA/ACCF Secondary Prevention and Risk Reduction Therapy for Patients with Coronary and other Atherosclerotic Vascular Disease: 2011 update: a guideline from the American Heart Association and American College of Cardiology Foundation. Circulation[Internet]. 2011[cited 2017 Apr 11];124(22):2458-73. Available from: http://circ.ahajournals. org/content/124/22/2458.long

9. World Health Organization-WHO. Global action plan for the prevention and control of noncommunicable diseases: 2013-2020[Internet]. Geneva: World Health Organization; 2013[cited 2017 Apr 11]. Available from: http://apps.who.int/iris/ bitstream/10665/94384/1/9789241506236_eng.pdf?ua =1

10. Gill R, Chow CM. Knowledge of heart disease and stroke among cardiology inpatients and outpatients in a Canadian inner-city urban hospital. Can J Cardiol[Internet] 2010[cited 2017 Apr 11];26(10):537-40. Available from: https://www.ncbi.nlm.nih.gov/ pmc/articles/PMC3006102

11. Furuya RK, Mata LR, Veras VS, Appoloni AH, Dantas RA, Silveira RC, et al. Original research: telephone follow-up for patients after myocardial revascularization: a systematic review. Am J Nurs[Internet]. 2013[cited 2017 Apr 11];113(5):28-31. Available from: http://journals.Iww.com/ajnonline/Fulltext/2013/05000/Original_Research__Telephone_Follow_Up_for.20.aspx

12. Stolic S, Mitchell M, Wollin J. Nurse-led telephone interventions for people with cardiac disease: a review of the research literature. Eur J Cardiovasc Nurs[Internet]. 2010[cited 2017 Apr 11];9(4):203-17. Available from: http://journals.sagepub.com/doi/pdf/10.1016/j. ejcnurse.2010.02.003

13. Ciconelli RM, Ferraz, MB, Santos W, Meinão I, Quaresma MR. Tradução para a língua portuguesa e validação do questionário genérico de avaliação de qualidade de vida SF-36 (Brasil SF-36). Rev Bras Reumatol. 1999;39(3):143-50.

14. Botega NJ, Bio MR, Zomignani MA, Garcia Jr C, Pereira WAB. Transtornos do humor em enfermaria de clínica médica e validação de escala de medida (HAD) de ansiedade e depressão. Rev Saúde Pública[Internet]. 1995[cited 2017 Apr 11];29(5):359-63. Available from: http://www.scielo.br/pdf/rsp/v29n5/04.pdf

15. Hanssen TA, Nordrehaug JE, Eide GE, Hanestad BR. Improving outcomes after myocardial infarction: a randomized controlled trial evaluating effects of a telephone follow-up intervention. Eur J Cardiovasc Prev Rehabil[Internet]. 2007[cited 2017 Apr 11];14(3):42937. Available from: http://journals.sagepub.com/doi/pdf/10.1097/HJR.0b013e32801da123

16. Hanssen TA, Nordrehaug JE, Eide GE, Hanestad BR. Does a telephone follow-up intervention for patients discharged with acute myocardial infarction have long-term effects on health-related quality of life? a randomised controlled trial. J Clin Nurs[Internet]. 2009[cited 2017 Apr 11];18(9):1334-45. Available from: http://onlinelibrary.wiley.com/doi/10.1111/j.1365-2702.2008.02654.x/pdf

17. Melamed RJ, Tillmann A, Kufleitner HE, Thürmer U, Dürsch M. Evaluating the efficacy of an education and treatment program for patients with coronary heart disease. Dtsch Arztebl Int[Internet]. 2014[cited 2017 Apr 11];111(47):802-8. Available from: https:// www.ncbi.nlm.nih.gov/pmc/articles/PMC4261555/pdf/Dtsch_Arztebl_Int-111-0802.pdf

18. Kotb A, Hsieh S, Wells GA. The effect of telephone support interventions on coronary artery disease (CAD) patient outcomes during cardiac rehabilitation: a systematic review and meta-analysis. PLoS One[Internet]. 2014[cited 2017 Apr 11];9(5):e96581. Available from: https://www.ncbi.nlm.nih.gov/pmc/articles/PMC4010507/pdf/pone.0096581.pdf

19. Ghisi GL, Santos RZ, Aranha EE, Nunes AD, Oh P, Benetti M, et al. Perceptions of barriers to cardiac rehabilitation use in Brazil. Vasc Health Risk Manag[Internet]. 2013[cited 2017 Oct 02];9:485-91. Available from: https://www.ncbi.nlm.nih.gov/pmc/articles/ PMC3770721/

20. Neubeck L, Redfern J, Fernandez R, Briffa T, Bauman A, Freedman SB. Telehealth interventions for the secondary prevention of coronary heart disease: a systematic review. Eur J Cardiovasc Prev Rehabil[Internet]. 2009[cited 2017 Oct 02];16(3):281-9. Available from: https://www.ncbi.nlm.nih.gov/pubmedhealth/PMH0028702/

21. Palacios J, Lee GA, Duaso M, Clifton A, Norman IJ, Richards D, et al. Internet-Delivered Self-management Support for Improving Coronary Heart Disease and Self-management-Related Outcomes: a systematic review. J Cardiovasc Nurs[Internet]. 2017[cited 2017 Oct 02];32(4):E9-E23. Available from: https://www.ncbi.nlm.nih.gov/pmc/articles/PMC5469565/

22. Grace SL, Turk-Adawi KI, Contractor A, Atrey A, Campbell NR, Derman W, et al. Cardiac rehabilitation delivery model for lowresource settings: an international council of cardiovascular prevention and rehabilitation consensus statement. Prog Cardiovasc Dis[Internet]. 2016[cited 2017 Oct 02];59(3):303-22. Available from: http://www.onlinepcd.com/article/S0033-0620(16)30081-0/pdf

23. Aldcroft SA, Taylor NF, Blackstock FC, O'Halloran PD. Psychoeducational rehabilitation for health behavior change in coronary artery disease: a systematic review of controlled trials. J Cardiopulm Rehabil Prev[Internet]. 2011[cited 2017 Oct 02];31(5):273-81. Available from: https://insights.ovid.com/pubmed?pmid $=21734590$ 